\title{
DAMPAK UNDANG-UNDANG NOMOR 12 TENTANG PANGAN TERHADAP KETAHANAN PANGAN INDONESIA
}

\author{
Ahmad Hadi ${ }^{1}$, Budiman Rusli ${ }^{2}$, Mohammad Benny Alexandri ${ }^{3}$ \\ ahmadhadinasri@gmail.com¹, budiman9560@gmail.com², mohammad.benny@unpad.ac.id³ \\ Program Pasca Sarjana Kebijakan Publik \\ Fakultas Ilmu Sosial dan Ilmu Politik \\ Universitas Padjadjaran
}

\begin{abstract}
ABSTRAK
Pangan adalah kebutuhan yang mendasar bagi manusia dan pemenuhannya merupakan hak asasi manusia yang di jamin oleh Undang-Undang Dasar 1945 dan negara berkewajiban untuk mewujudkan ketersedian, keterjangkauan, dan pemenuhan pangan yang cukup, aman, bermutu. Undang - Undang 18 Tahun 2012 Tentang Pangan adalah kebijakan yang ditetapkan oleh pemerintah untuk mewujudkan tugas negara untuk mewujudkan ketahanan pangan. Artikel ini mencoba untuk memahami bagaimana dampak dari UU 18 Tahun 2012 dalam menciptakan ketahanan pangan di Indonesia yang dinilai dari pilar ketahanan pangan, yaitu ketersediaan pangan, akses pangan, pemanfaatan pangan, dan stabilitas pangan. Artikel ini menyimpulkan bahwa kebijakan harus di revisi dengan memperhatikan pilar pilar ketahanan pangan.
\end{abstract}

Kata Kunci: Ketahanan Pangan, Kebijakan Pangan, Gizi Buruk

\begin{abstract}
Food is a basic need for humans and its fulfillment is a human right guaranteed by the 1945 Constitution and the state is obliged to realize the availability, affordability, and fulfillment of adequate, safe, quality food. Law 18 of 2012 concerning Food is a policy set by the government to realize the duty of the state to realize food security. This article tries to understand how the impact of Law 18 of 2012 in creating food security in Indonesia is assessed from the pillars of food security, namely food availability, food access, food utilization, and food stability. This article concludes that policies must be revised by taking into account the pillars of food security..
\end{abstract}

Keywords: Food Security, Food Policy, Malnutrition

\section{Pendahuluan}

Dalam laporan World Food Programme pada tahun 2016 terdapat 815 Juta orang mengalami kelaparan yang meningkat dari tahun sebelumnya yang berjumlah 777 juta orang yang tersebar di seluruh dunia terutama di negara-negara berkembang (FAO,2017). Indeks Kelaparan Global pada tahun 2018 menunjukkan bahwa tingkat kelaparan dan kekurangan gizi di dunia masuk dalam kategori serius (GHI, 2018)
.Berdasarkan laporan GHI tersebut Indonesia berada pada posisi yang serius dan jika dibandingkan dengan negara di ASEAN Indonesia hanya lebih baik dari Kamboja dan Laos, kemudian pada tahun 20184 warga Indonesia yang ada di Maluku meninggal karena kelaparan hal ini menujukkan bahwa belum seluruhnya masayarakat Indonesia yang mendapatkan keadilan pangan. 
Pada tahun 2012 ditetapkan UndangUndang Nomor 18 Tahun 2012 Tentang Pangan yang bertujuan untuk menciptakan ketahanan pangan atau food security. World Food Summit (1996) mendefiniskan ketahanan pangan adalah situasi dimana semua orang dapat mimiliki akses makanan yang cukup, aman, dan bergizi untuk memenuhi kebutuhan makanan mereka untuk mewujudkan kehidupan yang aktif dan sehat. Sedangkan menurut UU 18 Tahun 2012 ketahanan pangan adalah kondisi terpenuhinya pangan bagi negara sampai dengan perseorangan yang tercermin dari tersedianya pangan yang cukup, baik, jumlah maupun mutunya, aman, beragam, bergizi, merata, dan terjangkau serta tidak bertentangan dengan agama, keyakinan, dan budaya masyrakat untuk dapat hidup sehat, aktif, dan produktif secara berkelanjutan. Dua definisi ini menyimpulkan empat dimensi dalam ketahanan pangan yaitu akses, ketersedian, pemanfaatan, dan stabilitas.

Permasalahan kelaparan dan ketahanan pangan telah menjadi isu internasional dan masuk dalam tujuan pembangunan SDGs poin 2 yaitu mengakhiri kelaparan, mencapai ketahanan pangan dan nutrisi lebij baik dan mendukung pertanian berkelanjutan. Pada artikel ini akan mencoba untuk menganalisis dampak dari kebijakan pangan yang telah dikeluarkan oleh pemerintah Indonesia.

\section{MENGUKUR KETIDAKTAHANAN}

\section{PANGAN}

Ketahanan pangan merupakan sebuah konsep yang komplek dan multidimensi. Konsep ketahanan pangan tidak hanya memikirkan bagaimana menciptakan swasembada pangan yang focus terhadap produksi bahan pangan. Menurut FAO terdapat 4 dimensi didalam ketahanan pangan yaitu Ketersedian, Akses, Pemanfaatan, dan Stabilitas (FAO, 2013). Terdapat indicator untuk mengukur ketahanan pangan seperti ketersedian bahan pokok, prevalensi kekurangan gizi, kekurangan berat badan pada anak-anak dan BMI rendah padang orang dewasa.

Untuk ketersedian pangan Berdasarkan data yang dikeluarkan oleh BPS pada tahun 2018, Indonesia telah mampu meingkatkan produksi beras dengan jumlah 32,42 juta ton dengan perkiraan konsumsi beras nasional sebanyak 29,57 juta ton (https://www.bps.go.id/dynamictable/2019/04/ 15/1608/luas-panen-produksi-danproduktivitas-padi-menurut-provinsi2018.html). Hal ini menunjukkan bahwa Indonesia telah mampu memenuhi kebutuhan beras dalam negeri dengan surplus 2,85 juta ton.

Prevalensi kekurangan gizi digunakan oleh FAO untuk mengukur tingkat kelaparan dunia, menurut FAO pada tahun 2014-2016 terdapat 19,4 juta penduduk Indonesia yang mengalami kelaparan menurun dibandingkan tahun 1990-1992 yang mencapai 35,9 juta penduduk. (http://www.fao.org/indonesia/faoin-indonesia/indonesia-at-a-glance/en/). Jika dibandingkan dengan negara di asia tenggara tingkat kelaparan di Indonesia masih tergolong 
tinggi, indonesia hanya lebih baik jika dibandingkan dengan Laos dan kamboja.

Indikator selanjutnya adalah prevalensi berat badan pada anak balita atau dapat juga disebut dengan stunting yaitu masalah kurang gizi kronis yang disebabkan oleh kurangnya asupan gizi dalam waktu yang cukup lama, sehingga mengakibatkan gangguan pertumbuhan pada anak yakni tinggi badan anak lebih rendah atau pendek (kerdil) dari standar usianya. Pada tahun 2015 prevalensi stunting di Indonesia sebesar 36,4\% atau 8,8 juta balita mengalami masalah gizi yang berdampak pada pertumbuhan anak dan terbesar ke 2 di Asean setelah Laos 43,8\%, dan pada tahun 2017 mengalami penurun menjadi 29,6 (Kemenkes, 2018), .Angka ini masih di atas ambang batas yang telah ditetapkan oleh WHO sebesar 20\%. Dengan tingkat penurunan saat ini, Indonesia belum berhasil mengatasi permasalahan gizi pada anak.

Untuk mensederhanakan indicator di atas maka dapat dihitung denga GHI. Global Hunger Index (GHI) dihitung dengan menggabungkan tiga indikator kelaparan (IFPRI, 2013). Tiga indikator tersebut adalah penduduk yang kekurangan gizi, prevalensi kurang gizi pada anak di bawah lima tahun dan angka kematian pada anak di bawah lima tahun. Kondisi kelaparan di Indonesia pada tahun 2018 dengan skor GHI 21,9 masuk dalam kategori serius (GHI, 2018). Di Asia Tenggara Indonesia hanya lebih baik jika dibandingkan dengan Laos dan Kamboja sangat jauh jika dibandingkan dengan Thailaind yang memiliki score 10,4 .

Lembaga internasional seperti FAO, IFPRI menggunakan indicator ini untuk menilai tingkat kelaparan dan pencapaian SDGs poin 2 yaitu mengatasi kelaparan dan meciptakan ketahanan pangan. Pilar utama yang menentukan ketahanan pangan adalah (DKP,2009):

1. Ketersedian Pangan, yakni tersedianya pangan secara fisik di daerah, yang diperoleh baik dari hasil produksi domestic, impor, atau perdangangan maupun bantuan pangan. Ketersedian pangan ditentukan dari produksi domestic, jumlah impor, stok pedagang dan pemerintah serta bantuan.

2. Akses Pangan, yakni kemampuan rumah tangga untuk memperoleh cukup pangan, baik yang berasal dari produksi sendiri, pembelian, barter, hadiah, pinjaman, dan bantuan pangan maupun kombinasi kelimanya. Ketersediaan pangan suatu daerah boleh jadi mencukupi akan tetapi mungkin tidak semua rumah tangga memiliki akses yang memadai baik secara kuantitas maupun keragaman pangan.

3. Pemanfaatan pangan, yakni penggunaan pangan oleh rumah tangga, dan kemampuan individu untuk menyerap dan metabolisme 
zat gizi. Pemanfaatan pangan juga meliputi cara pengimpanan, penglolaan, dan penyiapan makanan termasuk penggunaan air dan bahan bakar selama proses pengolahannya serta kondisi kebersihan dan budaya.

Selain 3 pilar diatas, Gross (2000) menyatakan bahwa terdapat satu pilar yang juga menjadi pilar ketahanan pangan, yaitu stabilitas, stabilitas merupakan factor penentu yang mempengaruhi ketiga elemen di atas, stabilitas merupakan kemampuan untuk mendapatkan atau memperoleh pangan sepanjang waktu.

\section{Kekurangan Gizi Pada Anak Indonesia}

Dalam hal kekurangan gizi pada anak di Indonesia, pada tahun 2015 terdapat 8,8 juta balita yang mengalami stunting karena kekurangan gizi, jauh lebih buruk jika di bandingkan dengan negara tengga seperti Malaysia dan singapura, di ASEAN Indonesia hanya lebih baik dari Laos. Ini merupakan kondisi yang sangat buruk sehingga menjadi isu internasional maupun nasional dan isu ini menjadi perbincang dalam debat pilres 2019.

Kondisi gizi manusia tergantung pada empat factor yaitu akses makanan, perawatan, kesahatan, dan kebersihan lingkungan termasuk didalamnya sanitasi yang baik. Status gizi seseorang tergantung pada empat faktor akses ke makanan, perawatan, layanan kesehatan, dan kebersihan lingkungan dan sanitasi. Menurut Riset Kesehatan Dasar bahwa proporsi balita berusia 0 hingga 59 bulan dengan gizi buruk pada 2013 mencapai 19,6 persen angka ini meningkat dari 17,9 pesen pada 2010, (Kemenkes, 2013). jika dilihat berdasarkan provinsi ada 16 provinsi dengan proporsi balita gizi buruk diatas rata-rata, dan didominasi oleh di bagian indonesi timur, ini menunjukkan ada masalah dalam mendapapatkan akses terhadap makanan. Salah satu permasalahan dalam mewujudkan ketahanan pangan di Kawasan Indonesia Timur adalah masih besarnya potensi masyarakat yang mempunyai daya beli rendah dan tidak mempunyai akses terhadap pangan (Rachmaningsih,2012)

Tingkat pendidikan kepala keluarga dan pendidikan ibu berpengaruh terhadap pola asuh atau perwatan serta kesehatan anak. Pendidikan yang rendah menjadi pendorong munculnya gizi buruk terhadap anak karena pendidikan berpengaruh signifikan pada pengetahuan masyarkaat terhadap pola asuh dan kesehatan anak. Pendidikan mempengaruhi kualitas gizi anak, ketika pendidikan rendah maka pengetahuan terhadap kesehatan dan gizi menjadi rendah sehingga konsumsi gizi untuk anak semakin tidak baik berbalik jika pendidikan orang tua semakin baik maka semakin kecil resiko anak terkena gizi buruk (Saputra, 2012)

Factor terakhit yang mempengaruhi prevalensi gizi buruk terhadap anak adalah permasalahan sanitasi yang buruk seperti buang 
air sembarangan. Masalah sanitasi merupakan masalah lama yang belum terselesaikan. Menurut Badan Pusat Statisitk pada tahun 2017 rumah tangga yang memiliki akses sanitasi yang layak ada 67.89 persen. Berdasarkan data tersebut masih menyisahkan 32.1 persen rumah tangga di Indonesia yang tidak memiliki akses sanitas yang layak. Anak yang tidak mempunya akses terhadap sanitasi yang layak maka akan meningkatkan resiko untuk menderita stunting 1.3 kali lebih tinggi dibandingkan anak yang memiliki sanitasi yang baik ( Adiyanti, 2010).

\section{Undang-Undang Pangan Indonesia}

Dalam Undang-Undang Dasar 1945

dikatakan bahwa pemerintahan negara Indonesia di bentuk untuk melindungi segenap bangsa Indonesia dan seluruh tumpah darah Indonesia dan untuk memajukan kesejahteraan umum, dan pada pasal 27 ayat 2 tiap-tiap warga negara berhak atas pekerjaan dan penghidupan yang layak bagi kemanusian. Jadi dapat pahami bahwa pemerintah Indonesia bertanggung jawab untuk mewujudkan terciptanya kesejahteraan bagi rakyat agar mendapatkan penghidupan yang layak, pangan dan gizi merupakan kebutuhan dasar manusia dan pemenuhannya merupakan hak asasi manusia yang dijamin dalam Undang-Undang Dasar Negara Republik Indonesia Tahun 1945 untuk mewujudkan kesejahteraan dan kehidupan yang layak.

Untuk pelaksanaan hak rakyat atas pangan, maka di tetapkanlah Undang-Undang Nomor 18 Tahun 2012 tentang pangan yang mengantikan aturan sebelumnyanya yaitu Undang-Undang Nomor 7 Tahun 1996 Tentang Pangan, pada konsiderannya Undang-Undang ini ditetapkan untuk menimbang bahwa negara berkawajiban mewujudkan ketersedian, keterjangkauan, dan pemenuhan konsumsi pangan yang cukup, aman, bermutu, dan bergizi seimbang, baik pada tingkat nasional maupun daerah dalam artian bahwa pemerintah wajib untuk menciptakan ketahanan pangan bagi seluruh rakyat Indonesia sebagai upaya mewujudkan sumber daya manusia yang berkualitas sehingga tidak ada lagi ditemukan kasus krisis pangan hingga gizi buruk pada anak-anak Indonesia.

Undang-Undang Nomor 18 Tahun 2012 Tentang Pangan, merupakan kebijakan pangan yang yang landasan hokum bagi penyelenggaraan pangan yang mencakup perencanaan pangan, ketersedian pangan, keterjangkauan pangan, konsumsi pangan dan gizi, keamanan pangan, penelitian dan pengembangan pangan, kelembagaan pangan, peran serta masyarakat dan pendyedikan yang mengamanatkan untuk memenuhi kebutuhan dasar manusia yang memberikan manfaat secara adil, merata, dan berkelanjutan.

$$
\text { Undang-undang ini juga }
$$
mengamanatkan bahwa pemerintah bertanggung jawab dalam peneyediaan dan penyaluran pangan pokok sesuai kebutuhan, baik bagi masyarakat miskin, rawan pangan dan gizi, maupun dalam keadaan darurat unutuk mengatasi masalah pangan dan krisis pangan 
seperti permaslahan kelaparan dan kekurangan gizi. Namun dalam kebijakan ini tidak dijelaskan bagaimana upaya pemerintah dalam melaksanakan bantuan pangan bagi masyarakat yang mengalami krisis pangan khususnya bagi masayarakay yang kelaparan dan kekurang gizi.

\section{Dampak Undang-Undang Nomor 12 Tahun 2012 Tentang Pangan \\ Ketersediaan pangan adalah kondisi}

tersedianya pangan dari hasil produksi dalam negeri dan cadangan pangan nasional serta impor apbila kedua sumber utama tidak dapat memenuhi kebutuhan. Jadi dalam mewujudkan ketersedian pangan produksi dalam negeri merupakan prioritas untuk pemenuhan pangan nasional. Untuk komoditas beras sejak tahun 2014 hingga 2017 terus mengalami peningkatan.

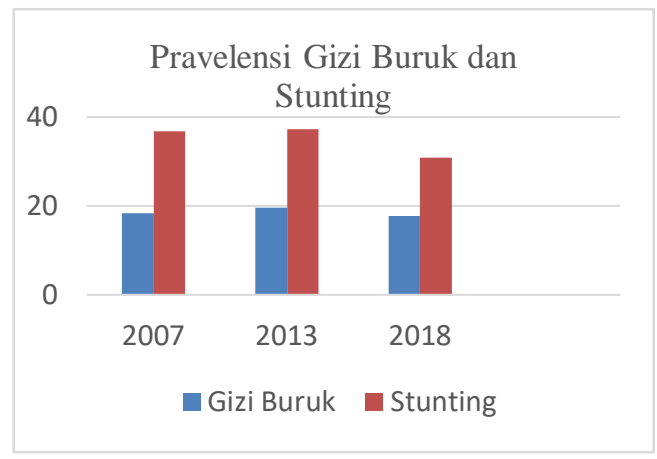

Sumber: Badan Pusat Statisitk, diolah

Berdasarkan gambar diatas menunjukkan bahwa Undang-Undang Nomor 18 tentang Pangan mampu mewujudkan ketersedian pangan dari hasil produksi dalam negeri, dimana setiap tahunnya produksi melebihi kebutuhan beras nasional. Jika melihat data yang dikeluarkan oleh BPS ini benar, lantas muncul sebuah pertanyaan besar mengapa pemerintah masih melakukan impor beras disaat produksi beras nasional indonesi

\section{Produksi dan Konsumsi} Beras

50

0

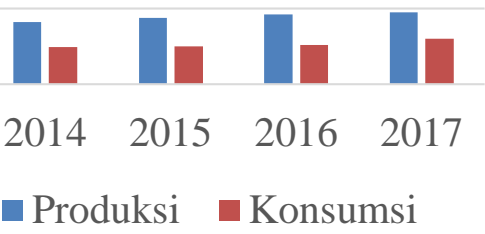

melebihi konsumsi nasional atau yang biasa disebut dengan surplus beras.

Akses pangan yaitu kondisi masyarakat untuk memperoleh kebutuhan pangan, biasanya diukur dengan prevalensi kurang gizi dan stunting atau hambatan pertumbuhan balita dalam populasi.

Sumber: Kemenkes, diolah

Undang-Undang Nomor 18 tentang Pangan belum mampu mengatasi permasalahan gizi buruk dan stunting dimana sejak tahun 2007 hingga 2018 tidak ada perubahan yang signifikan, bahkan angka gizi buruk dan stunting di Indonesia melebihi ketentuan wajar yang ditetapkan oleh WHO yakni 10\% untuk gizi buruk dan 20\% untuk stunting.

Untuk kemampuan akses pangan Indonesia bagian timur merupakan wilayah yang memiliki akses pangan yang sangat butuh perhatian, provinsi NTT dan Sulawesi Barat merupakan provinsi yang memiliki pravelsni gizi buruk dan stunting yang paling tinggi, bahkan pada tahun 2017 angka kematian bayi dan balita mencapai 1174. Ini merupakan tugas pemerintah meningkatkan akses pangan demi memenuhi hak pangan warga negara. 
Pemanfaatan pangan biasanya diukur dengan indikator antropometrik, indicator penentuan status gizi dengan memandingkan berat dengan tinggi, berat dengan usia dan tinggi dengan usia. Tujuannya untuk menghitung penggunaan pangan oleh rumah tangga dan kemampuan individu untuk menyerap gizi. Untuk Indonesia, angka pravelensi status gizi pada balita masih diatas ketentuan wajar WHO dan di ASEAN indonesia ada diurutan ke 2 yang paling buruk setelah Laos.

Sumber: katadata.co.id

Pemanfaatan pangan yang baik akan menciptakan sumber daya manusia yang berkualitas karena kebutuhan gizinya dapat terpenuhi. Dalam Undang-Undang Nomor 18 Tahun 2012 Tentang Pangan belum ada memuat mengenai pemanfaatan pangan.

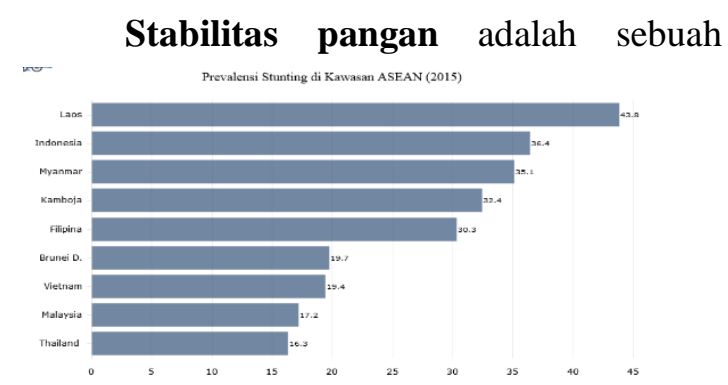

keadaan pangan yang stabil tanpa adanya pengaruh yang kekurangan atau keebihan pangan sehingga ada kemampuan masyarakat untuk membeli pangan, lonjakan inflasi akan mempengaruhi harga pangan kemudian akan memengaruhi status ketahanan pangan rumah tangga dan mendorong mereka ke dalam kemiskinan dan akibatnya muncul kondisi kerawanan pangan. Undang-Undang Nomor 18 Tahun 2012 mengamantkan bahwa pemerintah memiliki kewajiban untuk menciptakan stabilitas pasokan dan harga pangan unutk melindungi pendapatan produsen serta menjaga keterjangkauan konsumen.

\section{Sumber : Badan Pusat Statistik, diolah}

Jika dilihat dari gambar diatas dalam rentang 2014-2016 pada setiap tahunnya terjadi peningkatan harga bahan pokok namun tidak terjadi kenaikan cukup signifikan, pemerintah melaksanakan tanggung jawab dalam menekan harga kenaikan pangan dengan mengadakan operasi pasar pada saat terjadi lonjakan harga

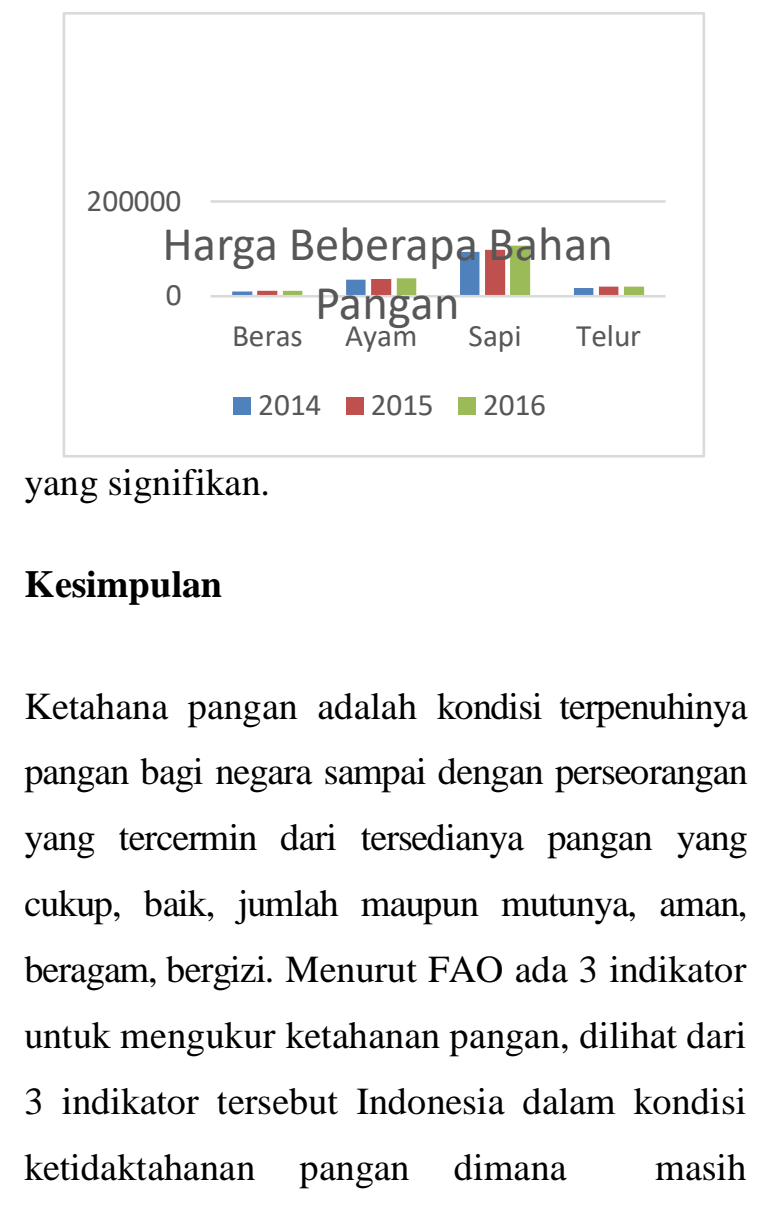


tingginya tingkat kelaparan dan gizi buruk pada balita, meskipun dalam produksi beras yang mencukupi. Dalam indek GHI Indonesia merupakan negara yang terburuk ke 2 di asia tenggara. Untuk menciptakan ketahan pangan seusai dengan kewajiban negara untuk menjamin setiap warga negara untuk mendapatkan pangan yang layak ini sesuai dengan UUD 1945 yakni warga negara berhak atas pekerjaan dan penghidupan yang layak bagi kemanusian, maka pemerintah mengeluarkan Undang-Undang Nomor 12 Tahun 2012 Tentang Pangan. Jika dinilai berdasarakan pilar ketahanan pangan, 2 pilar menjadi perhatian khusus bagi pemerintah yaitu untuk akses pangan diamana belum adanya kemudahan dan pemerataan akses pangan terutama bagi Indonesia bagian timur dan Undang-Undang Nomor 12 Tahun 2012 Tentang Pangan belum mengatur bagaimana pemanfaatan pangan dimana tingginya pravelensi gizi buruk pada anak. Untuk ketersedian pangan Indonesia, produksi dalam negeri telah mencapai surplus namun pemerintah belum mempriortaskan potensi pertanian dalam negeri. Yang terakhir stabilitas pangan yang mengalmi kenaikan namun tidak secara signifikan.

\section{Daftar Pustaka}

Adiyanti, Maya. (2014). Pola Asuh Gizi, Sanitasi Linkungan, Dan Pemanfaatan Posyandu Dengan Kejadian Stunting Pada Baduta Di Indonesia
Dewan Ketahanan Pangan. (2009). Peta Ketahanan dan Kerentanan Pangan Indonesia. Jakarta:Dewan Ketahanan Pangan BKP

FAO. (2013). The State Of Food Insecurity In The World. Dari http://www.fao.org/3/i3434e/i34 34e00.htm (diakses 10 Mei 2019)

FAO, IFAD, UNICEF, WFP and WHO. (2017). The State of Food Security and Nutrition in the World 2017. Dari http://www.fao.org/3/I9553EN/i 9553en.pdf (diakses 10 Mei 2019)

IFPRI (2013). Global hunger index: The challenge of hunger:Building resilience to achieve food and nutrition security. Bonn, Washington, DC, and Dublin: Welthungerhilfe, International Food Policy Research Institute, and Concern Worldwide.

Gross R.(2000). The Four Dimensions of Food and Nutrition Security:Definitions and Concepts. Switzerland : UN

Klaus von Grebmer, Jill Bernstein, et al. (2018). Global Hunger Index : Forced Migration And Hunger. Dublin:Concern Worldwide

Kemenkes. (2018). Situasi Balita Pendek (Stunting) di Indonesia.

Kemenkes. (2013). Riset Kesehatan Dasar.

Dari

http://www.depkes.go.id/resources/d ownload/general/Hasil\%20Riskesdas \%202013.pdf

Rachmaningsih, Triana. (2012). Ketahanan Pangan di Kawasan Timur Indonesia. Jurnal Ekonomi dan Pembangunan Indonesia 
Saputra, Wiko. (2012). Faktor Demografi dan Risiko Gizi Buruk dan Gizi Kurang Makara Kesehatan. 2012;16(2):95101.

World Food Summit (1996). Rome declaration on World FoodSecurity. Retrieved from

http://www.fao.org/wfs/index_en.ht m/ (akses 10 Mei 2019).

Undang-Undang Nomor 18 tentang Pangan 